\title{
Translating Effects of Inbreeding Depression on Component Vital Rates to Overall Population Growth in Endangered Bighorn Sheep
}

\author{
HEATHER E. JOHNSON, ${ }^{*}$ L. SCOTT MILLS, $\dagger$, JOHN D. WEHAUSEN, $\ddagger$ THOMAS R. STEPHENSON,$\S$ \\ AND GORDON LUIKART**
}

${ }^{*}$ University of Montana, Wildlife Biology Program, College of Forestry and Conservation, Missoula, MT 59812, U.S.A., email heather.johnson@state.co.us

†University of Montana, Wildlife Biology Program, College of Forestry and Conservation, Missoula, MT 59812, U.S.A. ‡White Mountain Research Station, University of California, 3000 East Line Street, Bishop, CA 93514, U.S.A.

$\S$ Sierra Nevada Bighorn Sheep Recovery Program, California Department of Fish and Game, 407 West Line Street, Bishop, CA 93514, U.S.A.

** University of Montana, Flathead Biological Station and Division of Biological Sciences, Polson, MT 59860, U.S.A. and the Centro de Investigação em Biodiversidade e Recursos Genéticos and Universidade do Porto (CIBIO-UP), Vairão, Portugal

\begin{abstract}
Evidence of inbreeding depression is commonly detected from the fitness traits of animals, yet its effects on population growth rates of endangered species are rarely assessed. We examined whether inbreeding depression was affecting Sierra Nevada bighorn sheep (Ovis canadensis sierrae), a subspecies listed as endangered under the U.S. Endangered Species Act. Our objectives were to characterize genetic variation in this subspecies; test whether inbreeding depression affects bighorn sheep vital rates (adult survival and female fecundity); evaluate whether inbreeding depression may limit subspecies recovery; and examine the potential for genetic management to increase population growth rates. Genetic variation in 4 populations of Sierra Nevada bighorn sheep was among the lowest reported for any wild bighorn sheep population, and our results suggest that inbreeding depression has reduced adult female fecundity. Despite this population sizes and growth rates predicted from matrix-based projection models demonstrated that inbreeding depression would not substantially inhibit the recovery of Sierra Nevada bighorn sheep populations in the next approximately 8 bighorn sheep generations (48 years). Furthermore, simulations of genetic rescue within the subspecies did not suggest that such activities would appreciably increase population sizes or growth rates during the period we modeled (10 bighorn sheep generations, 60 years). Only simulations that augmented the Mono Basin population with genetic variation from other subspecies, which is not currently a management option, predicted significant increases in population size. Although we recommend that recovery activities should minimize future losses of genetic variation, genetic effects within these endangered populations-either negative (inbreeding depression) or positive (within subspecies genetic rescue)-appear unlikely to dramatically compromise or stimulate short-term conservation efforts. The distinction between detecting the effects of inbreeding depression on a component vital rate (e.g., fecundity) and the effects of inbreeding depression on population growth underscores the importance of quantifying inbreeding costs relative to population dynamics to effectively manage endangered populations.
\end{abstract}


Keywords: endangered species, fecundity, Ovis canadensis sierrae, population growth, recovery, Sierra Nevada bighorn sheep

Traducción de los Efectos de la Depresión por Endogamia sobre Tasas Vitales Componentes del Crecimiento Poblacional de Ovis canadensis sierrae

Resumen: La evidencia de la depresión por endogamia comúnmente es detectada a partir de atributos de la adaptabilidad de animales, sin embargo sus efectos sobre las tasas de crecimiento poblacional raramente son evaluados. Examinamos si la depresión por endogamia estaba afectando a Ovis canadensis sierrae, una subespecie enlistada como en peligro en el Acta de Especies en Peligro de E.U.A. Nuestros objetivos fueron caracterizar la variación genética de esta subespecie; probar si la depresión por endogamia afecta las tasas vitales (supervivencia de adultos y fecundidad de bembras); evaluar si la depresión por endogamia puede limitar la recuperación dela subespecie y examinar el potencial para el manejo genético para incrementar las tasas de crecimiento poblacional. La variación genética en 4 subpoblaciones $O$. c. sierrae fue la más baja entre las reportadas para cualquier otra población silvestre de O. c. sierrae y nuestros resultados sugieren que la depresión por endogamia ha reducido la fecundidad de hembras adultas. Sin embargo, los tamaños poblacionales y tasas de crecimiento predichos por modelos de proyección matriciales demostraron que la depresión por endogamia no inhibiría sustancialmente la recuperación de O. c. sierrae en las próximas 8 generaciones ( 48 años). Más aun, simulaciones del rescate genético no sugirieron que tales actividades incrementarían los tamaños poblacionales o tasas de crecimiento durante el período modelado (10 generaciones, 60 años). Solo las simulaciones que aumentaron la población de Mono Basin con variación genética de otras subespecies, lo cual no es una opción de manejo actual, predijeron incrementos significativos en el tamaño poblacional. Aunque recomendamos que las actividades de recuperación deberían minimizar pérdidas futuras en la variación genética, parece poco probable que los efectos genéticos en estas poblaciones en peligro-ya sea negativas (depresión por endogamia) o positivas (rescate genético de la subespecie)_comprometan o estimulen dramáticamente los esfuerzos de conservación a corto plazo. La distinción entre la detección de los efectos de la depresión por endogamia sobre una tasa vital componente (e.g., fecundidad) y los efectos de la depresión por endogamia sobre el crecimiento poblacional resalta la importancia de cuantificar, mediante datos recolectados en campo, los costos de la endogamia en relación con la dinámica poblacional para el manejo efectivo de poblaciones en peligro.

Palabras Clave: crecimiento poblacional, especies en peligro, fecundidad, Ovis canadensis sierrae, recuperación

\section{Introduction}

Small populations are susceptible to inbreeding depression because mating between related animals can reduce individual and population fitness (Keller \& Waller 2002). The consequences of inbreeding depression are hard to predict because populations are affected differently, depending on demographic history, genetic diversity of the founders, occurrence of purging of deleterious alleles, severity of environmental conditions, and chance (Lacy et al. 1996; Lacy \& Ballou 1998; Bijlsma et al. 2000). Nevertheless, inbreeding depression can decrease the growth rates of populations and thus, reduce evolutionary potential and increase probability of extinction (Newman \& Pilson 1997; Saccheri et al. 1998; Hogg et al. 2006). As a result, genetic factors are often a major consideration in the conservation and recovery of threatened and endangered taxa.

Evidence of inbreeding depression in wild populations is commonly determined on the basis of heterozygosity-fitness correlations (Da Silva et al. 2006; Ortego et al. 2007; Mainguy et al. 2009). Whereas the effects of these correlations on population viabil- ity are often emphasized, they are rarely quantitatively assessed (Keller \& Waller 2002). A major limitation in linking findings from studies of inbreeding depression directly to population growth is the use of indirect fitness correlates, such as morphometric (e.g., body size) or physiological traits (e.g., parasite loads). These traits may be weakly correlated with individual fitness (Chapman et al. 2009) and cannot be easily used to assess population-level fitness. Even when heterozygosity-fitness correlations are directly related to demographic vital rates (survival and reproductive rates) (i.e., Coulson et al. 1999; Cohas et al. 2009), and thus individual fitness, the link between inbreeding depression and population dynamics is rarely quantified. Because different vital rates disproportionately affect the growth rates of populations (Mills 2007), significant heterozygosity-fitness correlations-even those related to vital rates-may not affect populations in any measurable way. As a result, to properly examine the influence of inbreeding depression on wild populations, genetic variability should be evaluated relative to those vital rates that have the greatest effect on population growth (Mills \& Smouse 1994). This is critical for conser- 
vation because it allows one to assess whether genetic factors are limiting populations and the potential for genetic rescue to stimulate recovery efforts (Tallmon et al. 2004).

We examined whether inbreeding depression was affecting Sierra Nevada bighorn sheep (Ovis canadensis sierrae) (hereafter bighorn sheep), a subspecies listed as endangered under the U.S. Endangered Species Act. This is the rarest subspecies of bighorn sheep in North America, with approximately 400 individuals in 2009. Levels of heterozygosity in this subspecies were reported to be among the lowest of any wild bighorn sheep population in the United States (U.S. Fish and Wildlife Service 2007) and were comparable to those for Rocky Mountain bighorn sheep (O. c. canadensis) in the National Bison Range, where inbreeding depression was associated with multiple fitness traits (Hogg et al. 2006). Bighorn sheep populations have a history of demographic bottlenecks, isolation, and small size, which have raised substantial concerns that genetic factors may limit their recovery.

To assess whether inbreeding depression may inhibit recovery efforts, we quantified genetic variation of bighorn sheep with respect to adult survival and adult female fecundity rates. These vital rates explain $>80 \%$ of the variation in the growth rates of bighorn sheep populations (Johnson et al. 2010). We evaluated genetic variation at neutral markers (Wright 1951) and potentially adaptive markers expected to be more closely tied to individual fitness (Luikart et al. 2003). Our objectives were to characterize genetic variation in bighorn sheep; test whether inbreeding depression was affecting bighorn sheep vital rates (adult survival and fecundity); evaluate whether inbreeding depression may limit subspecies recovery; and examine the ability of genetic rescue (i.e., gene flow) to stimulate population growth rates.

\section{Methods}

\section{Study Populations}

In the late 1970s, with a minimum of 220 individuals (Wehausen 1980), the Baxter-Sawmill (hereafter Baxter) population was the largest of the last 2 remaining populations of bighorn sheep in the Sierra Nevada. That population was subsequently used as source stock for reintroducing 3 additional populations, Wheeler, Langley, and Mono Basin, in 1979, 1980, and 1986, respectively (Supporting Information). These herds were located along approximately $200 \mathrm{~km}$ of the Sierra Nevada crest, and each population was geographically isolated so their $\mathrm{dy}$ namics were independent (we use population and herd synonymously throughout the text). The range of the Mono Basin population lies partially in Yosemite National Park, ranges of the Baxter and Langley populations lie partially in Sequoia-Kings Canyon National Park and the

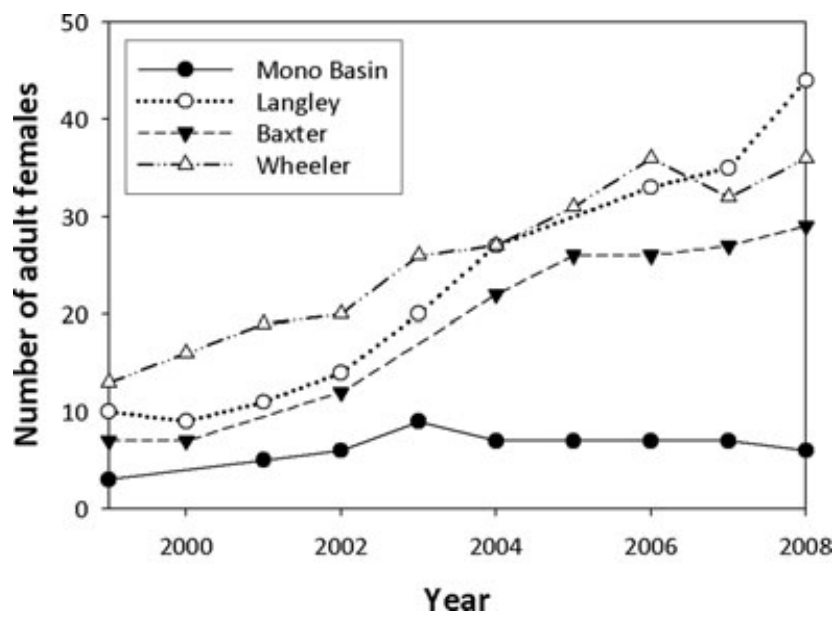

Figure 1. Number of adult females in the Wheeler, Langley, Baxter, and Mono Basin populations of Sierra Nevada bighorn sheep, 1999-2008. Numbers are from annual minimum counts (see the text), except for Wheeler and Langley from 2006 to 2008, which are from mark-resight estimates.

remainder of the study area is managed by the Inyo and Sierra National Forests. By 1998, across all populations, field surveys detected only about 125 adult bighorn sheep (U.S. Fish and Wildlife Service 2007). As a result, in 1999, bighorn sheep were listed as endangered by the U.S. Fish and Wildlife Service. Since then the Wheeler, Baxter, and Langley populations have increased considerably in size, whereas the Mono Basin population has remained small $(\leq 11$ adult females) (Fig. 1).

\section{Field Sampling}

From 1995 to 2007 annual counts of the minimum number of bighorn sheep in the Mono Basin, Wheeler, and Langley populations were performed by experienced observers, who systematically hiked through and scanned the area occupied by each herd to detect bighorn sheep, which were differentiated by gender and stage class. Due to small population sizes and repeated surveys, in many cases counts were complete, or nearly complete, censuses of individuals in each stage class (for survey details see Johnson et al. [2010]). We used data from consecutive annual counts to estimate population-specific vital rates needed to parameterize bighorn sheep population models.

To relate vital rates to inbreeding depression, we also tracked the survival and reproduction (female) of marked individuals with known genotypes. Between 1999 and 2009, California Department of Fish and Game captured male and female bighorn sheep with helicopter net guns. Blood for DNA analysis was taken from captured animals. A radio collar with a unique frequency and a mortality sensor was placed on each bighorn sheep. Collared bighorn 
sheep were tracked on the ground and from fixed-wing aircraft twice per month to monitor survival. Adult females were located and observed in July or August each year to determine whether they had lambs. Females give birth to 1 offspring/year, and each collared female was recorded as successfully reproducing if it was observed nursing a lamb.

\section{Microsatellite Analyses}

We extracted DNA from blood samples of 128 individual bighorn sheep: 26 from Baxter, 21 from Langley, 29 from Mono Basin, and 52 from Wheeler. We used polymerase chain reactions to amplify microsatellite markers and to genotype each individual (see Supporting Information for details). We genotyped 29 microsatellite loci known to be polymorphic in Ovis species. We assumed 18 were neutral (not in or near known genes) and 11 were located in potentially adaptive genes on the basis of studies of other ungulates (Supporting Information). Neutral loci were AE16, AE129, BM4513, CP20, FCB11, FCB128, FCB193, FCB266, FCB304, HH47, HH62, HH64, JMP29, MAF33, MAF36, MAF48, MAF65, and MAF209. Potentially adaptive loci were ADC, BL4, IGF, KERA, MHCI, MMP9, OIFNG, OLA, SOMA, TCRB, and TGLA387. From those loci that appeared selectively neutral (Supporting Information), we calculated observed and expected heterozygosity, allelic richness, and genetic differentiation $\left(F_{S T}\right.$ and Jost's $\left.D\right)$ of bighorn sheep populations.

\section{Testing for the Effects of Inbreeding Depression on Component Vital Rates}

To test for inbreeding depression, we calculated individual multilocus heterozygosity of each marked animal (b) (Mitton 1993). We evaluated heterozygosity across all polymorphic loci that behaved neutrally (no evidence of being under selection [Supporting Information]), regardless of whether the marker was initially considered neutral or potentially adaptive. We also calculated individual mean $d^{2}$ (the average squared distance in repeat units between 2 alleles at any typed locus for an individual [Coulson et al. 1998]), but found no association between $d^{2}$ and bighorn sheep fitness traits and thus do not report results of these analyses.

We based our examination of the relation between genetic variation and adult survival and female fecundity on individual multilocus heterozygosity. For each vital rate, we developed a minimal nongenetic model that tested the explanatory power of covariates known or hypothesized to be important for ungulates (Da Silva et al. 2009; Mainguy et al. 2009). We included population as a categorical variable; the Baxter population was the reference class. We also evaluated the effect of age and age ${ }^{2}$ on vital rates to account for potential asymptotic or curvilinear effects. We used the Akaike information criterion (Burnham \& Anderson 2002) corrected for small sample sizes $\left(\mathrm{AIC}_{\mathrm{c}}\right)$ and model weights to evaluate models.

To assess those covariates that affect annual adult survival, we used semiparametric Cox proportional hazards models (Cox 1972; Cleves et al. 2008). We used a studybased time scale for analysis (Fieberg \& DelGiudice 2009) and considered each animal to be at risk of death from the time it was collared until its collar was heard emitting a mortality signal or it was censored at the end of the study (1 September 2009). We assessed annual survival based on a biological year from 15 April to 14 April of the following year. In addition to age, age ${ }^{2}$, and population, we included gender and a gender-by-age interaction as covariates.

To model adult female fecundity, we used logistic mixed-effects models (Rabe-Hesketh \& Skrondal 2008). Because annual fecundity of each radio-collared female was monitored for between 1 and 7 years (depending on the length of time collared), we used random effects to account for individually marked bighorn sheep.

Once we identified the best nongenetic model for each vital rate, we added heterozygosity to determine whether genetic factors explained additional variation in survival and fecundity rates. To determine whether genetic factors were evident only in particular populations, we accounted for interactions between population and heterozygosity variables. We used deviance residuals, link tests, and $\chi^{2}$ statistics to examine model fit (McCullagh \& Nelder 1989; Cleves et al. 2008). For survival models, we also evaluated the proportional hazards assumption by testing for an interaction between covariates and time and by checking Schoenfeld residuals (Cleves et al. 2008); no violations were detected.

Our objective was to use multilocus heterozygosity as a proxy for genome-wide inbreeding (Da Silva et al. 2009; Mainguy et al. 2009), so we evaluated each significant multilocus heterozygosity model to ensure that it was not driven by individual loci. We tested for locus-specific effects by adding the heterozygosity of each individual locus to our best nongenetic model to determine whether that locus significantly improved the model. If a locusspecific effect improved model fit, we recalculated multilocus $b$ without the locus and retested for effects of multilocus heterozygosity. If the removal of specific loci altered the relation of a vital rate to multilocus genetic variation, we assumed our results were driven by locus specific, as opposed to genome-wide, effects (Balloux et al. 2004).

\section{Quantifying Population-Level Effects of Inbreeding}

We predicted the demographic consequences of inbreeding depression on subspecies recovery by incorporating the effects of inbreeding on vital rates in female-based matrix projection models. We estimated the long-term 
influence of inbreeding depression on population growth rates, given current heterozygosity values and future expected losses of heterozygosity. We also simulated an increase in heterozygosity (genetic rescue), potentially associated with management, to predict effects on population growth rates.

We first determined the rate at which heterozygosity would be expected to be lost in these bighorn sheep populations. Because we did not have genetic data collected at 2 discrete points in time (temporal lag), we used a onesample estimator in the program LDNe (Waples 2006) to estimate the approximate effective population size $\left(N_{e}\right)$. We then estimated expected loss of heterozygosity per generation (Wright 1951):

$$
H_{1}=\left(1-\frac{1}{2 N_{e}}\right) H_{0},
$$

where $H_{0}$ is the initial multilocus heterozygosity of a population and $H_{1}$ is the heterozygosity expected after one generation. We used a generation time of 6 years because this was the average age at which female bighorn sheep reproduced in our study. Using our vital rate inbreeding models, we then estimated the percent decrease in vital rates expected to occur (per generation) given the predicted loss in heterozygosity. We simulated these effects for the Mono Basin and Langley populations because detailed demographic data were available for both herds, and they represented minimum and maximum population growth rates observed in bighorn sheep (Fig. 1) (Johnson et al. 2010).

To assess the influence of inbreeding depression on population growth rates, we inserted estimates of inbreeding depression, which were based on data collected in the field from marked animals, into stochastic, postbirth pulse, matrix population projection models that estimated the stochastic population growth rate $\left(\lambda_{s}\right)$ or the mean lifetime fitness of individuals in a population (Lande 1982; Tuljapurkar et al. 2009). The basic matrix models are described in detail in Johnson et al. (2010), so we describe them briefly here.

Matrix models were stage- and female-based and limited to those classes of bighorn sheep that could be distinguished reliably during annual ground surveys: adults, yearlings, and lambs. Vital rates describing annual changes in those stage classes were adult female survival, yearling female survival, and adult female fecundity. To parameterize matrix projections, we used means and variances of vital rates estimated from annual population counts. We used field data collected from 1996 through 2007 on the Langley population and from 1999 to 2007 on the Mono Basin population to estimate populationspecific vital rates. We initialized population vectors from ground counts conducted in 2008. Matrix projections included only process variance in vital rates and accounted for demographic stochasticity (Mills \& Smouse 1994). For each modeled scenario, we calculated the mean $\lambda_{s}$ and expected median population size $\left(N_{t}\right)$ from 1000 replicate simulations.

We first projected population dynamics assuming no inbreeding depression (i.e., baseline) and then decremented vital rates to incorporate the accumulation of inbreeding depression, as detected in fecundity rates. The effect of inbreeding depression on fecundity rates was originally estimated from marked animals of both male and female lambs. To account for the fact that only female lambs were included in matrix projections, we multiplied the expected reduction in fecundity by 0.5 . We modeled the effect of inbreeding depression on bighorn sheep populations for 1-10 generations, decreasing fecundity rates on the basis of inbreeding depression each generation, as specified by our fecundity-heterozygosity model. Although we changed mean vital rates in the matrix models to reflect inbreeding effects, we maintained our original estimates of variance around those rates.

To simulate genetic rescue, we modeled population responses to increasing average multilocus heterozygosity. We conducted management simulations only for the Mono Basin population because this was the herd of greatest management concern and the only one that had not increased substantially in abundance in recent years (Fig. 1). We used the same matrix approach described above, but increased baseline fecundity rates according to expectations from 2 levels of enhanced heterozygosity given our initial vital rate models. We first simulated the growth rate of the Mono Basin population with an increase in average heterozygosity (currently $b=0.43$ ) equal to that of the source herd, Baxter $(b=0.48)$, our measure of genetic rescue within the subspecies. Second, we modeled the growth rate of the Mono Basin population with an average increase in heterozygosity to 0.59 , the mean heterozygosity of 8 other populations of Rocky Mountain and desert bighorn sheep (O. c. nelsoni) (Forbes \& Hogg 1999). In practice, achieving this level of heterozygosity would require translocations from other bighorn subspecies (i.e., outside genetic rescue).

\section{Results}

\section{Genetic Variation}

Of the 29 loci we genotyped, 4 were monomorphic across populations (FCB128, FCB266, IGF, and OINF). The 25 polymorphic loci had between 2 and 5 alleles/locus (Supporting Information; mean $[\mathrm{SD}]=2.84$ [0.17]). Ten alleles of a total of 71 had frequencies $<5 \%$ in any population, and there were 3 private alleles, one in each of the Baxter, Wheeler, and Mono Basin populations. Of the polymorphic loci, 17 met neutral expectations, and we used these to calculate metrics of genetic variation (12 initially considered neutral, 5 potentially adaptive; Supporting Information): ADC, AE129, 
Table 1. Model selection metrics ${ }^{a}$ for adult survival (Cox proportional hazard models) and female fecundity (logistic mixed-effects models) of Sierra Nevada bighorn sheep (California, U.S.A.).

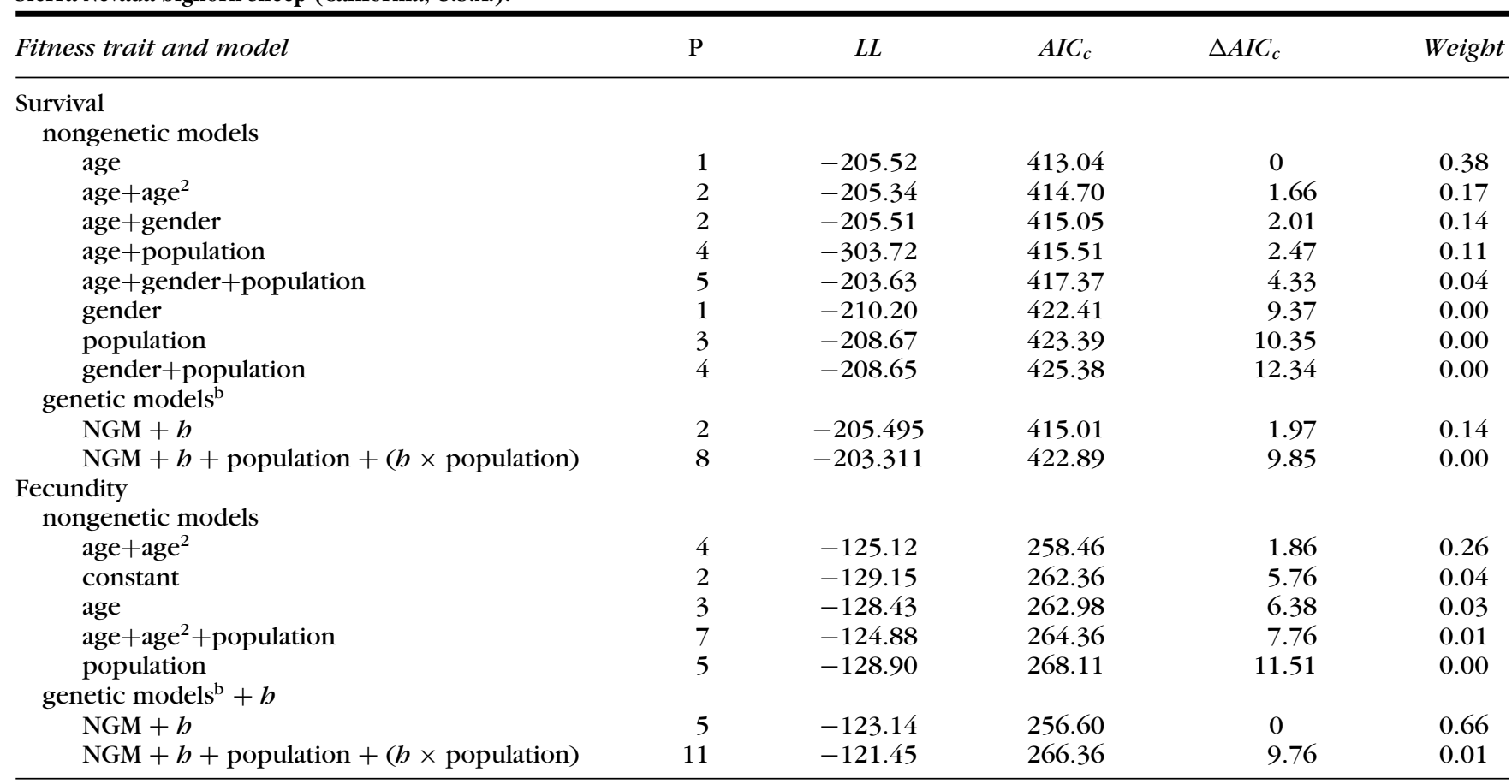

a Metrics: $\mathrm{P}$, number of model parameters; LL, log likelibood; AIC, , Akaike's information criterion; weight, values of AIC model weight.

${ }^{b}$ The best nongenetic model (NGM) for each vital rate was first identified and then multilocus beterozygosity (h) was added to the best nongenetic model to determine whether this addition improved model fit.

BL4, BM4513, FCB11, FCB193, FCB304, HH47, HH62, KERA, MAF33, MAF36, MAF48, MAF65, MAF209, TCRB, and TGLA387.

Population-specific expected heterozygosity values ranged from 0.33 to 0.39 when all loci were included (monomorphic and polymorphic) and from 0.40 to 0.48 when only polymorphic loci were included (Supporting Information). Heterozygosity values were lowest in the Langley population and highest in Baxter, the source population (Supporting Information). Allelic richness was similar among populations; mean number of alleles/locus ranged from 2.35 to 2.59 . There were significant differences in allele frequencies among all pairs of populations (all Fisher's exact tests for pairwise $F_{S T}$ comparisons $\chi^{2} \geq$ 118 , df $=34, p<0.001$ ), although Jost's $D$ estimates varied little among populations. Pairwise $F_{S T}$ values ranged from 0.04 to 0.08 (global $F_{S T}=0.06$ ), and pairwise Jost's $D$ values ranged from 0.015 to 0.027 (Supporting Information).

\section{Detecting the Effects of Inbreeding Depression on} Component Vital Rates

Multilocus heterozygosity of individual bighorn sheep was between 0.24 and 0.76 . Mean population values were $0.47,0.41,0.48$, and 0.44 for the Baxter, Langley, Mono Basin, and Wheeler populations, respectively (all SE 0.02). Of the 128 bighorn sheep whose survival we monitored, 51 died. The best nongenetic model of adult survival included only age as a covariate (Table 1 ), with mortality risk increasing in older animals (Table $2 ; \chi^{2}=$ $9.62, p<0.01$ ). The addition of multilocus heterozygosity did not significantly improve the fit of the survival model, which suggests inbreeding depression did not affect this vital rate (Table 1 ).

We obtained 194 observations of annual reproductive status from 75 radio-collared females that were genotyped. Our best nongenetic fecundity model included age and age $^{2}$ as covariates (Tables $1 \& 2 ; \chi^{2}=5.82, p=$ $0.05)$. The annual probability of reproducing was low for the very young and very old and highest for intermediate ages. On the basis of $\mathrm{AIC}_{\mathrm{c}}$ values and model weights, the addition of multilocus $\boldsymbol{b}$ improved model fit and individuals across all populations with higher heterozygosity had higher probabilities of reproducing (Fig. 2; Tables $1 \& 2$; $\left.\chi^{2}=8.58, p<0.05\right)$. There was no evidence of locusspecific fecundity effects (Supporting Information).

\section{Effect of Inbreeding Depression on Population Dynamics}

The estimate of $N_{e}$ was 11 (95\% CI 7-18) for Mono Basin and 13 (95\% CI 7-27) for Langley. For these $N_{e}$ values, we estimated genetic drift would decrease heterozygosity by $0.020 /$ generation in Mono Basin and by 0.015 /generation in Langley. Pairing these losses of heterozygosity with our estimates of inbreeding costs translated to a $1.2 \%$ decrease in annual fecundity/generation for Mono Basin and a $1.4 \%$ decrease/generation for Langley. 
Table 2. Model parameter coefficients ( $\beta$ and SE) for the effects of age and individual heterozygosity (b) on adult survival (Cox proportional hazard model) and female fecundity (logistic mixed-effects models) of Sierra Nevada bighorn sheep given the best nongenetic and genetic models.

\begin{tabular}{|c|c|c|c|c|}
\hline Model parameter & $\beta$ & $S E$ & $\beta$ & $S E$ \\
\hline \multicolumn{5}{|l|}{ Female fecundity } \\
\hline intercept & -1.04 & 0.94 & -2.68 & 1.31 \\
\hline$b$ & - & - & 3.42 & 1.79 \\
\hline
\end{tabular}

${ }^{*}$ We do not report parameter coefficients for the genetic model of adult survival because the inclusion of heterozygosity did not improve model fit.

When mean fecundity values were decremented in population projection models, $\lambda_{s}$ did not appreciably decline over the modeled period (Table 3 ). For Mono Basin, mean $\lambda_{s}$ values from inbreeding depression scenarios were not significantly different from baseline scenarios, and after 10 generations (60 years) inbreeding depression decreased $\lambda_{s}$ from 1.017 to 1.016 (Table $3 \&$ Fig. $3)$. This difference in $\lambda_{s}$ did not result in a significant reduction in median $N_{t}$ values from baseline to inbreeding depression scenarios until after 8 generations ( 48 years; Fig. 3). For Langley, $\lambda_{s}$ values were significantly less than baseline scenarios after 3 generations (18 years), but had limited biological effect. The high growth rate in the Langley population was predicted to decrease by $0.5 \%$ after 10 generations, from 1.180 to 1.174 (Table 3).

When modeling the effects of genetic rescue from individuals within the Sierra Nevada for the Mono Basin

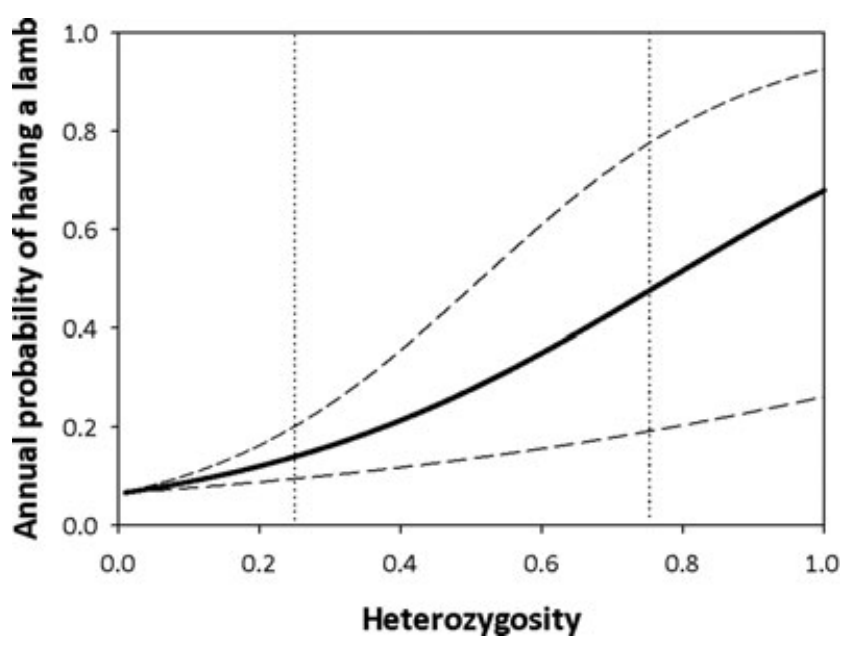

Figure 2. Annual fecundity rates (SE) for adult female Sierra Nevada bighorn sheep as a function of individual multilocus beterozygosity. Predictions are from a logistic mixed-effects regression model with all other effects beld constant. Vertical dotted lines at 0.24 and 0.76 represent the observed range of individual multilocus beterozygosity values. population, we found $\lambda_{s}$ was not significantly higher than either the baseline or inbreeding depression predictions after 10 generations (Table 3 ) and $N_{t}$ was statistically indistinguishable from baseline projections until generation 10 (Fig. 3). Conversely, when we simulated the effects of genetic rescue from individuals outside the Sierra Nevada, $\lambda_{s}$ was significantly higher than baseline predictions after the first generation (Table 3 ) and resulted in significantly higher predictions of $N_{t}$ (Fig. 3). For example, after 10 generations an estimated $1.3 \%$ increase in mean $\lambda_{s}$ (Table 3) would be expected to increase the predicted population size by $56 \%$, with $N_{t}$ after 60 years predicted to be 179 individuals compared with 115 under baseline conditions (Fig. 3).

\section{Discussion}

Despite evidence that inbreeding depression reduced bighorn sheep fecundity rates (Fig. 2), inbreeding depression appears unlikely to appreciably inhibit population growth of bighorn sheep in the next approximately 8 generations ( 48 years). Although the population ecology literature recognizes that all vital rates are not equal in their effects on population growth (Morris \& Doak 2002; Mills 2007) this principle has not been applied to most studies of inbreeding depression. Rather, researchers often infer from statistically significant heterozygosity-fitness correlations that population growth or viability is being substantially reduced. Fecundity, for example, is often evaluated in studies on inbreeding depression (Ralls et al. 1988; Orteg et al. 2007). By applying our observed fecundity decrement to models of population growth for 10 generations (60 years), however, we found that the values and variation of other vital rates ameliorated the reduction in reproduction caused by inbreeding depression (Table 3). This is not to say that inbreeding depression does not significantly affect the growth rates of endangered populations; rather, its influence depends on which vital rates are affected, the values of other vital rates, and the generation time of the species. Our 
Table 3. Means (95\% CI) of stochastic population growth rates for the Mono Basin and Langley populations of Sierra Nevada bighorn sheep under current heterozygosity levels (baseline), under the expected effects of inbreeding depression, and under scenarios in which heterozygosity at Mono Basin is simulated to increase to 0.48 and 0.59 .

\begin{tabular}{lcccc}
\hline Population & Baseline & Inbreeding depression & $\mathrm{h}=0.48$ & $\mathrm{~h}=0.59$ \\
\hline $\begin{array}{l}\text { Mono Basin } \\
\text { 1 generation }\end{array}$ & $1.027(1.024-1.030)$ & $1.023(1.020-1.026)$ & $1.027(1.024-1.031)$ & $1.034(1.030-1.037)$ \\
$\quad 5$ generations & $1.023(1.018-1.028)$ & $1.021(1.017-1.025)$ & $1.025(1.021-1.030)$ & $1.033(1.030-1.036)^{*}$ \\
$\quad$ 10 generations & $1.017(1.010-1.024)$ & $1.016(1.010-1.022)$ & $1.024(1.018-1.029)$ & $1.030(1.024-1.035)^{*}$ \\
Langley & & & - & - \\
$\quad \begin{array}{l}\text { 1 generation } \\
\text { g generations }\end{array}$ & $1.189(1.189-1.190)$ & $1.188(1.187-1.189)$ & - & - \\
$\quad 10$ generations & $1.180(1.180-1.181)$ & $1.174(1.174-1.175)^{*}$ & - & - \\
\hline
\end{tabular}

*The $95 \%$ CIs do not overlap those from the baseline scenario.

simulations demonstrated that inbreeding depression is expected to significantly decrease the predicted size of the Mono Basin population after approximately 8 generations (Fig. 3), but given the relatively small contribution of fecundity to population growth and the long generation time of bighorn sheep, this effect will be insignificant in the near term. This distinction between detecting effects of inbreeding depression on a component vital rate and on population growth rates underscores the importance of assessing inbreeding depression relative to population dynamics to effectively manage small and endangered populations.

Low genetic variation of bighorn sheep herds matched known population histories and had implications for the

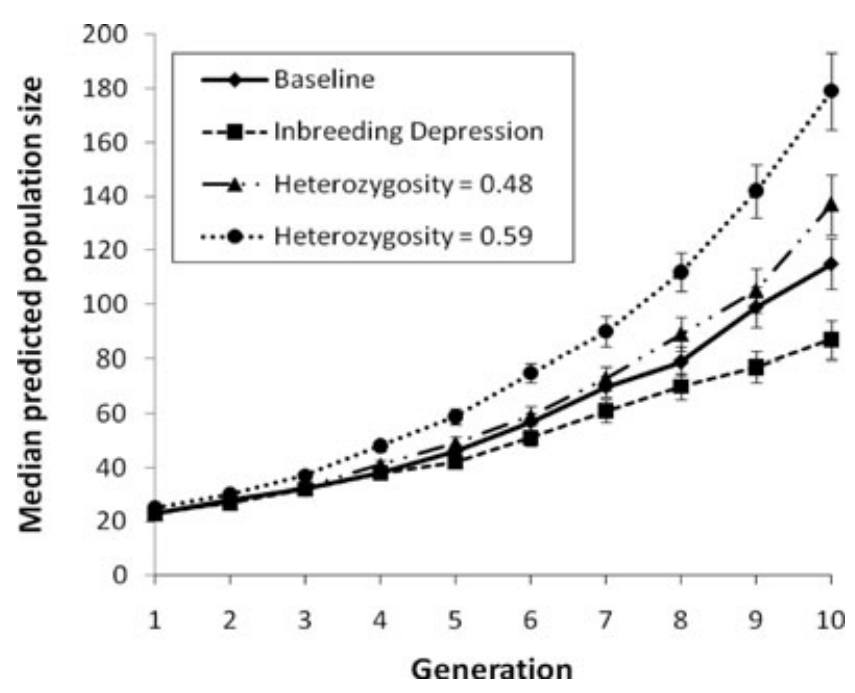

Figure 3. Predicted size of the Mono Basin bighorn sheep population over 10 generations (60 years) if beterozygosity $(\mathrm{h})$ remains unchanged $(\mathrm{h}=0.43$, baseline), if inbreeding depression continues to reduce $\mathrm{h}$ (inbreeding depression), if average $\mathrm{h}$ increases to 0.48 (mean value of the source population [Baxter]), and if average $\mathrm{h}$ increases to 0.59 (mean value of other Rocky Mountain and desert bighorn sheep populations). effectiveness of genetic rescue. As expected, genetic variation in Sierra Nevada bighorn sheep was lower than genetic variation in Rocky Mountain or desert bighorn sheep populations (Boyce et al. 1997; Forbes \& Hogg 1999; Gutiérrez-Espeleta et al. 2000). Probably due to this limited variation, we found that genetic rescue with individuals from within the Sierra Nevada was not expected to substantially increase growth rates in the Mono Basin population until generation 10 (Fig. 3). Significant increases in population size in response to genetic rescue only occurred if we simulated an increase in heterozygosity to a magnitude representative of populations of Rocky Mountain or desert bighorn sheep subspecies (Table 3 Fig. 3). Such an increase in heterozygosity, and thus fecundity rates, would only be achievable through cross-subspecies translocations, a management option not being considered at this time. Other management activities, such as disease prevention, habitat enhancement, and predator control may result in greater shortterm increases in the population growth rate than withinsubspecies genetic rescue (U.S. Fish and Wildlife Service 2007; Clifford et al. 2009; Johnson et al. 2010).

Although inbreeding depression was predicted to have a negligible effect on population growth in the next few decades, model results were consistent with genomewide inbreeding expectations. Fecundity was associated with multilocus heterozygosity even after accounting for locus-specific effects. Furthermore, although there was evidence for a heterozygosity-fitness correlation in fecundity, we did not detect such a correlation with adult survival. This is consistent with observations that inbreeding depression is stronger in younger age classes than in older age classes (Cohas et al. 2009) because individuals with unfit genotypes likely die young.

Our model simulations were based entirely on demographic data collected in the field, which may not account for some factors that could influence predicted population sizes. For example, our models did not include the potential effects of heterosis or hybrid vigor, in which an influx of genetic material may cause individual fitness to increase more than expected, particularly if there is a fixed genetic load (Tallmon et al. 2004). They also did 
not take into account that natural selection may purge deleterious recessive alleles in some populations, which may reduce inbreeding effects (Templeton \& Read 1984; Bouzat 2010). This phenomenon, however, is variable and often absent (Ballou 1997; Byers \& Waller 1999). Additionally, while we could estimate all stage-specific vital rates from annual counts of animals to project population sizes, we could not estimate heterozygosity-fitness correlations for yearling survival (because yearlings were not captured routinely). Extensive demographic modeling of bighorn sheep has demonstrated that yearling survival explains $0 \%$ to $18 \%$ of the variation in population growth rates (Johnson et al. 2010), which makes it unlikely that the effects of inbreeding depression on this rate would qualitatively change our results. Finally, our matrix models were based on the life cycle of females because these were the data available and because we assumed female vital rates were driving population trends in this polygamous species. Whereas female-based matrices are common for polygamous species, it is possible that skewed male reproductive success could increase the effect of drift and inbreeding depression. This effect, however, would not be expected to substantially change our results over the time frames we modeled.

Other features of the model may also have influenced our results. For example, we chose to model the mean effect of inbreeding depression on fecundity rates, rather than a stochastic effect, to clearly illustrate how a fixed decrement in a common fitness trait would influence population growth. We would not expect the inclusion of stochasticity in this parameter to qualitatively change our results, but it could increase the variability in our estimates of $\lambda_{s}$. Additionally, we estimated expected losses of heterozygosity with a 1-sample $N_{e}$ estimator. For overlapping generations, a 2-sample estimator with genetic data from 2 separate time points would have been more appropriate, but such data were not available. To ensure our results were not strongly influenced by $N_{e}$ estimates, we also ran models with the lower and upper 95\% CI values of $N_{e}$, which spanned a $N_{e} / N_{c}$ ratio of approximately $0.10-0.35$ for Langley and $0.20-0.50$ for Mono Basin and are comparable to those of bighorn sheep at the National Bison Range (Hogg et al. 2006) and general findings from animal populations in the wild (Frankham 1995). For both populations there were no qualitative differences in the results.

Our analysis highlights the importance of not only detecting heterozygosity-fitness correlations in endangered populations, but also relating estimates of inbreeding depression to the vital rates that drive population growth. Such approaches should be highly beneficial for guiding conservation decisions about threatened and endangered species. For example, genetic effects within the small Mono Basin population-either negative (inbreeding depression) or positive (genetic rescue with individuals from within the Sierra Nevada)-were not expected to significantly influence recovery in the next 8 bighorn sheep generations ( 48 years). Thus, we suggest the recovery program for this subspecies focus on maintaining genetic variation by enhancing gene flow among existing herds and on nongenetic management activities predicted to yield greater near-term population gains. For example, management actions, such as predator management and disease prevention, may have a greater influence on population viability over the next 10-20 years than genetic management (Johnson et al. 2010; Cahn et al. 2011).

\section{Supporting Information}

A map of the locations of Sierra Nevada bighorn sheep populations (Appendix S1), microsatellite analyses used to characterize genetic variation (Appendix S2), locusspecific genetic variation (Appendix S3), estimates of population-specific genetic variation (Appendix S4), population pairwise $F_{S T}$ and $D$ values (Appendix S5), and model selection results from testing for locus-specific fecundity effects (Appendix S6) are available online. The authors are solely responsible for the content and functionality of these materials. Queries (other than absence of the material) should be directed to the corresponding author.

\section{Acknowledgments}

We thank the people that collected field data including L. Bowermaster, M. Cahn, K. Chang, K. Ellis, J. Erlenbach, D. German, B. Gonzalez, A. Feinberg, J. Fusaro, L. Greene, D. Jensen, M. Kiner, L. Konde, K. Knox, B. Pierce, C. Schroeder, and staff from Landells Aviation and Quicksilver Air. We thank C. Hartway for help with MatLab programming. D. Pletscher, M. Hebblewhite, H. Robinson, E. Fleishman, L. Laikre, P. Hedrick, and anonymous reviewers provided constructive comments on this manuscript. We also thank the California Department of Fish \& Game and the Canon Science Scholars Program for supporting this work. L.S.M. acknowledges the National Science Foundation (DEB-0841884) and G. L. was supported by research grants from the U.S. National Science Foundation, the Walton Family Foundation, and the Portuguese Science Foundation.

\section{Literature Cited}

Ballou, J. D. 1997. Ancestral inbreeding only minimally affects inbreeding depression in mammalian populations. Journal of Heredity 88:169-178.

Balloux, F., W. Amos, and T. Coulson. 2004. Does heterozygosity estimate inbreeding in real populations? Molecular Ecology 13:3021-3031

Bijlsma, R., J. Bundgaard, and A. C. Boerema. 2000. Does inbreeding affect the extinction risk of small populations? Predictions from 
Drosophila. Journal of Evolutionary Biology 13:502-514.

Bouzat, J. L. 2010. Conservation genetics of population bottlenecks: the role of chance, selection, and history. Conservation Genetics 11:463-478.

Boyce, W. M., P. W. Hedrick, N. E. Muggli-Cockett, S. Kalinowski, M. C. T. Penedo, and R. R. Ramey II. 1997. Genetic variation of major histocompatibility complex and microsatellite loci: a comparison in bighorn sheep. Genetics 145:421-433.

Burnham, K. P., and D. R. Anderson. 2002. Model selection and multimodel inference: a practical information-theoretic approach. 4th edition. Springer, New York.

Byers, D. L., and D. M. Waller. 1999. Do plant populations purge their genetic load? Effects of population size and mating history on inbreeding depression. Annual Review of Ecology and Systematics 30:479-513.

Cahn, M. L., M. M. Conner, O. J. Schmitz, T. R. Stephenson, J. D. Wehausen, and H. E. Johnson. 2011. Disease, population viability and recovery of endangered Sierra Nevada bighorn sheep. Journal of Wildlife Management: in press.

Chapman, J. R., S. Nakagawa, D. W. Coltman, J. Slate, and B. C. Sheldon. 2009. A quantitative review of heterozygosity-fitness correlations in animal populations. Molecular Ecology 18:2746-2765.

Cleves, M., W. Gould, R. G. Gutierrez, and Y. U. Marchenko. 2008. An introduction to survival analysis using Stata. 2nd edition. Stata Press, College Station, Texas.

Clifford, D. L., B. A. Schumaker, T. R. Stephenson, V. C. Bleich, M. L. Cahn, B. J. Gonzales, W. M. Boyce, and J. A. K. Mazet. 2009. Assessing disease risk at the wildlife-lifestock interface: a study of Sierra Nevada bighorn sheep. Biological Conservation 142:2559-2568.

Cohas, A., C. Bonenfant, B. Kempenaers, and D. Allaine. 2009. Agespecific effect of heterozygosity on survival in alpine marmots, Marmota marmota. Molecular Ecology 18:1491-1503.

Coulson, T., S. Albon, J. Slate, and J. Pemberton. 1999. Microsatellite loci reveal sex-dependent responses to inbreeding and outbreeding in red deer calves. Evolution 53:1951-1960.

Coulson, T. N., J. M. Pemberton, S. D. Albon, M. Beaumont, T. C. Marshall, J. Slate, F. E. Guinness, and T. H. Clutton-Brock. 1998. Microsatellites reveal heterosis in red deer. Proceedings of the Royal Society of London Series B 265:489-495.

Cox, D. R. 1972. Regression models and life-tables (with discussion). Journal of the Royal Statistical Society. Series B 34:187-220.

Da Silva, A., et al. 2009. Heterozygosity-fitness correlations revealed by neutral and candidate gene markers in roe deer from a long-term study. Evolution 63:403-417.

Da Silva, A., G. Luikart, N. G. Yoccoz, A. Cohas, and D. Allainé. 2006. Genetic diversity-fitness correlation revealed by microsatellite analyses in European alpine marmots (Marmota marmota). Conservation Genetics 7:371-382.

Fieberg, J., and G. D. DelGiudice. 2009. What time is it? Choice of time origin and scale in extended proportional hazards models. Ecology 90:1687-1697.

Forbes, S. H., and J. T. Hogg. 1999. Assessing population structure at high levels of differentiation: microsatellite comparisons of bighorn sheep and large carnivores. Animal Conservation 2:223-233.

Frankham, R. 1995. Effective population size/adult population size ratios in wildlife: a review. Genetical Research 66:95-107.

Gutiérrez-Espeleta, G. A., S. T. Kalinowski, W. M. Boyce, and P. W. Hedrick. 2000. Genetic variation and population structure in desert bighorn sheep: implications for conservation. Conservation Genetics 1:3-15.

Hogg, J. T., S. H. Forbes, B. M. Steele, and G. Luikart. 2006. Genetic rescue of an insular population of large mammals. Proceedings of the Royal Society of London Series B 273:1491-1499.

Johnson, H. E., L. S. Mills, J. Wehausen, and T. R. Stephenson. 2010. Population-specific vital rate contributions influence management of an endangered ungulate. Ecological Applications 20: 1753-1765.

Keller, L. F., and D. M. Waller. 2002. Inbreeding effects in wild populations. Trends in Ecology \& Evolution 17:230-241.

Lacy, R. C., G. Alaks, and A. Walsh. 1996. Hierarchical analysis of inbreeding depression in Peromyscus polionotus. Evolution 50:2187-2200.

Lacy, R. C., and J. D. Ballou. 1998. Effectiveness of selection in reducing the genetic load in populations of Peromyscus polionotus during generations of inbreeding. Evolution 52:900-909.

Lande, R. 1982. A quantitative genetic theory of life-history evolution. Ecology 63:607-615.

Luikart, G., P. R. England, D. Tallmon, S. Jordan, and P. Taberlet. 2003. The power and promise of population genomics: from genotyping to genome typing. Nature Reviews Genetics 4:981-994.

Mainguy, J., S. D. Côté, and D. W. Coltman. 2009. Multilocus heterozygosity, parental relatedness and individual fitness components in a wild mountain goat, Oreamnos americanus population. Molecular Ecology 18:2297-2306.

McCullagh, P., and J. A. Nelder. 1989. Generalized linear models. 2nd edition. Chapman and Hall, London.

Mills, L. S. 2007. Conservation of wildlife populations: demography, genetics and management. Blackwell Publishing, Malden, Massachusetts.

Mills, L. S., and P. E. Smouse. 1994. Demographic consequences of inbreeding in remnant populations. The American Naturalist 144:412431.

Mitton, J. B. 1993. Theory and data pertinent to the relationship between heterozygosity and fitness. Pages $17-41$ in N. W. Thornhill, editor. The natural history of inbreeding and outbreeding. University of Chicago Press, Chicago.

Morris, W. F., and D. F. Doak. 2002. Quantitative conservation biology: theory and practice of population viability. Sinauer Associates, Sunderland, Massachusetts.

Newman, D., and D. Pilson. 1997. Increased probability of extinction due to decreased genetic effective population size: experimental populations of Clarkia pulchella. Evolution 51:354-362.

Ortego, J., G. Calabuig, P. J. Cordero, and J. M. Aparicio. 2007. Egg production and individual genetic diversity in lesser kestrels. Molecular Ecology 16:2383-2392.

Rabe-Hesketh, S., and A. Skrondal. 2008. Multilevel and longitudinal modeling using Stata. 2nd edition. Stata Press, College Station, Texas.

Ralls, K., J. D. Ballou, and A. Templeton. 1988. Estimates of lethal equivalents and the cost of inbreeding in mammals. Conservation Biology 2:185-193.

Saccheri, I., M. Kuussaari, M. Kankare, P. Vikman, W. Fortelius, and I. Hanski. 1998. Inbreeding and extinction in a butterfly metapopulation. Nature 392:491-494.

Tallmon, D. A., G. Luikart, and R. S. Waples. 2004. The alluring simplicity and complex reality of genetic rescue. Trends in Ecology \& Evolution 19:489-496.

Templeton, A. R., and B. Read. 1984. Factors eliminating inbreeding depression in a captive herd of Speke's gazelle. Zoo Biology 3:177199.

Tuljapurkar, S., J.-M. Gaillard, and T. Coulson. 2009. From stochastic environments to life histories and back. Philosophical Transactions of the Royal Society Series B 364:1499-1509.

U.S. Fish and Wildlife Service. 2007. Recovery plan for the Sierra Nevada bighorn sheep. Sacramento, California.

Waples, R. S. 2006. A bias correction for estimates of effective population size based on linkage disequilibrium at unlinked gene loci. Conservation Genetics 7:167-184.

Wehausen, J. D. 1980. Sierra Nevada bighorn sheep: history and population ecology. PhD dissertation. University of Michigan, Ann Arbor.

Wright, S. 1951. The genetical structure of populations. Annals of Eugenics 15:323-354. 